\title{
Low-density debris flows and floods modeling in the Susuya river basin
}

\author{
Viktoriia Kurovskaia ${ }^{1 *}$, Tatyana Vinogradova ${ }^{2}$, and Anastasiia Vasiakina $^{3}$ \\ ${ }^{1}$ Lomonosov Moscow State University, GSP-1, Leninskie Gory, 119991, Moscow, Russia \\ ${ }^{2}$ Saint Petersburg State University, 7/9 Universitetskaya nab, 199034, St. Petersburg, Russia \\ ${ }^{3}$ University of South-Eastern Norway, Gullbringvegen, 36, 3800, Bø i Midt-Telemark, Norway
}

\begin{abstract}
Significant area of Yuzhno-Sakhalinsk city within the river Susuya flood plain, a terrace above it and its tributaries are located in flood prone zone. The aim of this research was to estimate maximum characteristics of flash floods and low-density debris flows for the Susuya river and its tributaries, the Rogatka and Vladimirovka rivers. A onedimensional model of unsteady water movement based on Saint-Venan equations was used. The modeling of river maximum characteristics include following tasks: 1) collect and analyze the data of past dangerous events, 2) process the initial information for the model, 3) simulate discharges of $0.1-10 \%$ exceeding probabilities with a change in the hydraulic-morphometric characteristics of the objects. The model does not take into account flow density, therefore numerical experiments were conducted with the increasing coefficient of roughness to identify optimal values of the parameter. The results can be further used in the construction design of residential buildings and infrastructure in Yuzhno-Sakhalinsk.
\end{abstract}

\section{Introduction}

During the warm period from June to October several floods may occur in the Sakhalin island [1]. This area has a monsoon climate with typhoons which may result in multiday rains. For example, the amount of precipitation for the period from 1 to 7 August, 1981 (typhoons Odzhin and Phyllis) in Makarov city was $215 \mathrm{~mm}$ with the monthly norm of 99 $\mathrm{mm}$ and in Yuzhno-Sakhalinsk city $-220 \mathrm{~mm}$ with the norm of $94 \mathrm{~mm}$ [2]. Besides, debris flows are formed in the channels of mountain rivers and their tributaries. After being saturated with water, the debris flow became diluted and transform into low-density flows. The frequency of debris flow formation is once in every 3-5 years, the catastrophic ones occur every 20-25 years [3].The approximate urban area of Yuzhno-Sakhalinsk is 160000 ha, while the area of debris flow prone zone is 1566 ha [4]. Almost the entire territory, within the floodplain and the first floodplain terrace of the Susuya river and its tributaries, is located in the floods prone area. The main objects of destructions are motor and rail roads, bridges and houses. The are 2 active hydrological gauges on the Susuya river. The

*Corresponding author: viktoriiakurovskaia@gmail.com 
first one is located in the village Sanatorium $20 \mathrm{~km}$ from the city of Yuzhno-Sakhalinsk (gauge code: 04116), where water discharges and water levels are measured. Another gauge is located in Yuzhno-Sakhalinsk (gauge code: 04118), where only water levels are measured. However, there are no active hydrological gauges on the Rogatka and Vladimirovka rivers. Nowadays only unregular one-time measuremets of hydrological characteristics on the river Sysya tributaries are conducted. The aim of this study was to model the hydrographs of floods and low-density debris flows of different exceeding probabilities for the Susuya river gauge within the territory of Yuzhno-Sakhalinsk and its tributaries, in particular the Rogatka and the Vladimirovka rivers. A one-dimension model based on Saint-Venant equations was used in this study.

\section{Methods}

The features of this model include the relative simplicity of the required initial information, the lack of calibration from the observed data, as well as a large block of information obtained for all cross-sections (discharges, water-levels, cross-sectional area, flow width, Reynolds number, Froude number). The model was successfully applied and used for the experiments to simulate a release wave from the reservoirs on the Svir, Ob, Yenisei and Oredezh rivers in order to compare field measurements and model results [5-6]. A numerical scheme developed at Lavrentyev Institute of Hydrodynamics of the Siberian Branch of the Russian Academy of Sciencve was incorporated into the model [7]. Differential equations of the unsteady flow in open waterways in the presence of tributary inflow were used:

$$
\begin{gathered}
I=i_{o}-\frac{\partial h}{\partial x}=\frac{\alpha}{g} V \frac{\partial V}{\partial x}+\frac{\beta}{g} \frac{\partial V}{\partial t}+\frac{V|V|}{C^{2} R}+\frac{q V}{g w}, \\
\frac{\partial w}{\partial t}+\frac{\partial Q}{\partial x}=q
\end{gathered}
$$

in (1) and (2) equations, $x$ is the downstream coordinate, $t$ is the time (hours), $h$ is the flow depth $(\mathrm{m}), V$ is the average velocity $(\mathrm{m} / \mathrm{s}), Q$ is the water-sediment discharge $\left(\mathrm{m}^{3} / \mathrm{s}\right), \omega$ is the cross-section area occupied by the flow $\left(\mathrm{m}^{2}\right), C$ is the Chezy friction factor, $g$ is the gravity acceleration $\left(\mathrm{m} / \mathrm{s}^{2}\right), R$ is area border ratio $(\mathrm{m}), \alpha$ and $\beta$ parameters depending on the shape of the cross-section and $q$ is the tributary inflow $\left(\mathrm{m}^{3} / \mathrm{s}\right)$. Before the calculations, the river bed was divided into several sections. The boundary of the sections was anchored to the cross-sections, for which the data of observed discharges and water levels were available. The initial data included the depth and the width of the cross-sections, duration of the hazard event, initial and maximum discharges and water levels at the cross-sections.

\section{Study areas}

The fisrt study area was the Vladimirovka river. It flows in the Sakhalin region and originates from the the Mitsul Ridge. The river length is $24 \mathrm{~km}$ with the catchment area of $57.2 \mathrm{~km}^{2}$. It enters the Susuya river from $33 \mathrm{~km}$ above its mouth [8]. A steep longitudinal profile with absolute elevations up to 680 meters is observed in the upper reaches of the Vladimirovka river. Then the slope decreases towards the lower reaches, the relief changes to the plain one. At the confluence with the Susuya river (the lower part of YuzhnoSakhalinsk city) floods are often observed in the warm period due to intense snow melting [9].

The second study area was the Rogatka river, which flows through Yuzhno-Sakhalinsk city. The absolute elevation of the basin varies from 580 to $220 \mathrm{~m}$. The river source is 
located on the Susunai Range. Further, the river flows from the left bank into the Susuya river tributary - the Krasnoselskaia river. The river length is $10 \mathrm{~km}$, the catchment area is $43 \mathrm{~km}^{2}$ [10]. In the upper reaches, the river has a mountainous relief, which, after entering the Susuya river valley, changes into an anthropogenic one. During the summer period, severe floods increase lateral and bottom erosion, deforming the existing protective structures built on the river and causing floods in Yuzhno-Sakhalinsk [9]. Debris flows occur every $10-15$ years with the average volume of 50 thousand $\mathrm{m}^{3}$, but can reach more than 300 thousand $\mathrm{m}^{3}$ [10]. During the typhoon Phyllis, the debris flow left loose material in the water reservoir [11].

Our last study area was the Susuya river, one of the two largest rivers in the southern Sakhalin. It flows from the eastern slope of the Mitsul Ridge, at the foot of Svetlaya (790 $\mathrm{m})$ and enters Aniva Bay of the Okhotsk Sea. The river length is $83 \mathrm{~km}$ with the catchment area of $823 \mathrm{~km}^{2}$, the total river fall is $500 \mathrm{~m}$, and the average slope is $6.0 \%$ [8]. For the period from 1947 to 2015, more than 10 floods were recorded with significant damage of the city and surrounding settlements: 1947, 1955, 1970, 1972, 1978, 1981, 2002, 2009, 2012, 2015.

\section{Results}

The initial information about the channel morphometry, as well as the cases for setting the maximum discharges for the first cross-sections (initial condition) and water-levels for the ultimate ones (boundary condition) with different exceeding probabilities were provided by the employees of the Research Center "Geodinamika" (Table).

Table 1. Adopted cases for modeling for the Susuya, the Vladimirovla and Rogatka rivers [9].

\begin{tabular}{|c|c|c|c|c|c|c|c|}
\hline $\begin{array}{c}\text { No. } \\
\text { of } \\
\text { case }\end{array}$ & $\begin{array}{c}\text { Exceeding } \\
\text { probability, } \\
\%\end{array}$ & $\begin{array}{c}\text { Qmax, } \\
\mathrm{m}^{3} / \mathrm{s} . \\
\mathrm{R} . \\
\text { Susuya }\end{array}$ & $\begin{array}{c}\text { Hmax, } \\
\mathrm{m} . \\
\mathrm{R} .\end{array}$ & $\begin{array}{c}\text { Qmax, } \mathrm{m}^{3} / \mathrm{s} . \\
\mathrm{R} .\end{array}$ & $\begin{array}{c}\text { Hmax, } \mathrm{m} . \\
\mathrm{R} .\end{array}$ \\
\hline 1 & 10 & 256.9 & 23 & 27.5 & 61.5 & 41 & 61.5 \\
\hline 2 & 1 & 522.8 & 24.1 & 57.2 & 62.7 & 74.1 & 61.8 \\
\hline 3 & 0.1 & 779.5 & 24.9 & 86.3 & 63 & 110.3 & 62 \\
\hline
\end{tabular}

The calculation of the Susuya river maximum discharges was carried out according to the reduction formula. The maximum characteristics for the Vladimirovka river were obtained by the reduction formula with an analogue river, for which the Susuya river in the upper reaches (area $94.5 \mathrm{~km}^{2}$ ) was selected. The calculation of maximum discharges for the Rogatka river was carried out according to the ultimate flow rate formula [9].

According to water discharge measurements (gauge code: 04056), a flood was observed at the Vladimirovka river and lasted from 06.08.1981 till 08.08.1981 with the maximum discharge of $20 \mathrm{~m}^{3} / \mathrm{s}$ [8]. The calculation was conducted for the river section that is located from $2300 \mathrm{~m}$ upstream from the Lermontov bridge to $100 \mathrm{~m}$ downstream from it. In the applied model, a friable material, which was involved into the stream during debris flow, was not taken into account. However, we considered the flow density by the means of the coefficient of roughness. Therefore, it is possible to model not only floods, but also lowdensity debris flows. Due to the fact that there are no established limits for changes in the coefficient of roughness for different flows, we conducted several numerical experiments to investigate the optimal one. In this case, optimal one was equal to 0.09 for all crosssections. The figure below shows the hydrographs of the flood and low-density debris flow of various exceeding probabilities at the $3^{\text {rd }}$ cross-section. The maximum discharge at the 
$3^{\text {rd }}$ cross-section was $103.2 \mathrm{~m}^{3} / \mathrm{s}$ at $49^{\text {th }}$ hour, which was obtained for the Vladimirovka river by the model.

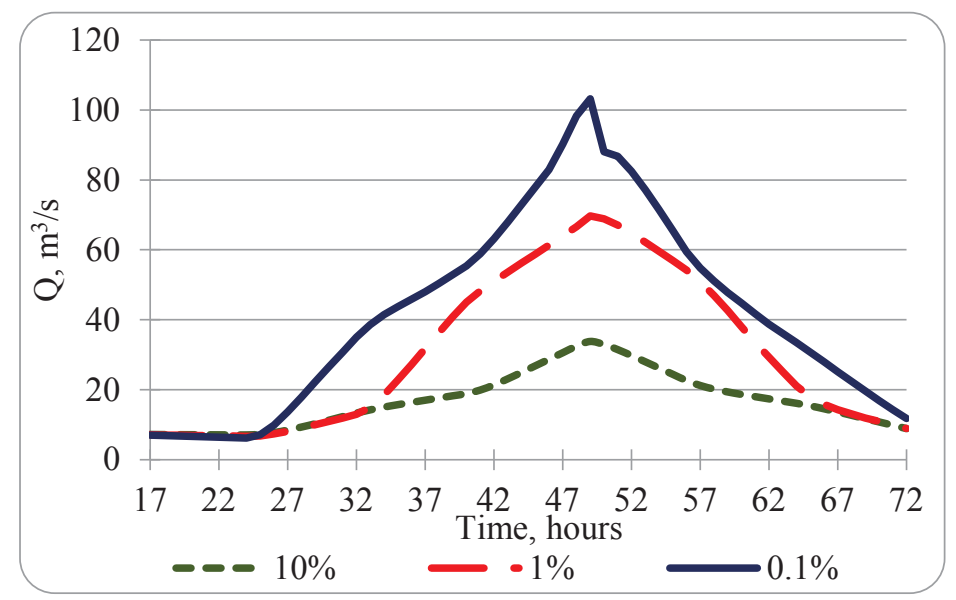

Fig. 1. Calculated hydrographs of various exceeding probabilities for the $3^{\text {rd }}$ cross-section of the Vladimirovka River.

The water-level for the $1^{\text {st }}$ cross-section varied from $25.3 \mathrm{~m}$ (exceeding probability of $0.1 \%)$ to $24 \mathrm{~m}(10 \%)$. Flooding of the territory at the $3^{\text {rd }}$ cross-section, which is located $500 \mathrm{~m}$ before the mouth, occurs at the depth of 1.2 and $1.5 \mathrm{~m}$ for 1 and 3 cases of modeling respectively.

The length of the Rogatka river modeled section was $887 \mathrm{~m}$. It is located $287 \mathrm{~m}$ upstream from the pedestrian bridge on the street Dzerzhinsky and 600 meters downstream in $1.7 \mathrm{~km}$ before the mouth.

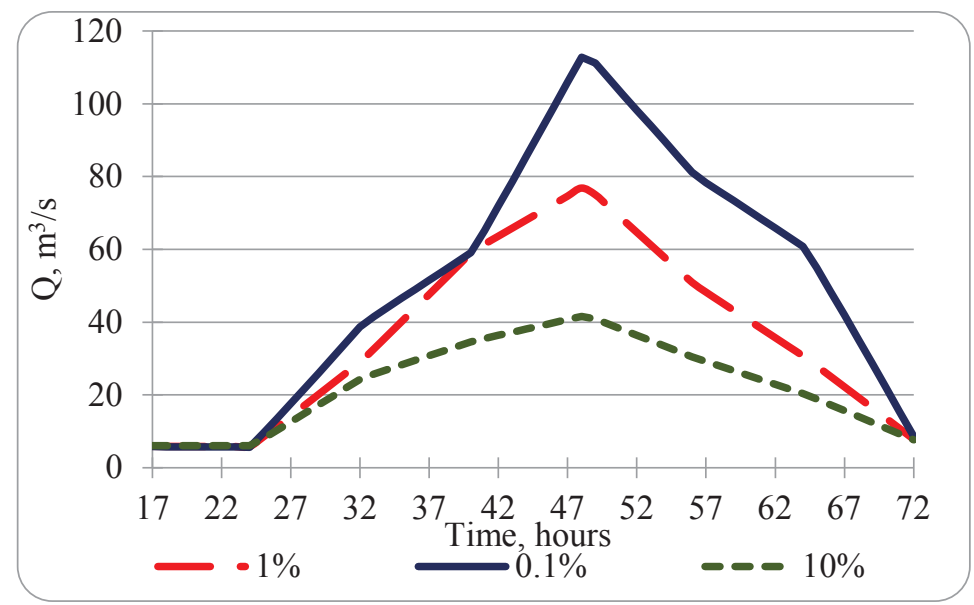

Fig. 2. Calculated hydrographs of various exceeding probabilities for the $3^{\text {rd }}$ cross-section of the Rogatka River.

During typhoon Phillis according to [10] the debris flow lasted from 4 till 5 August of 1981. This flow destroyed hydrological gauge (gauge code: 04122) and the data for the study period were not preserved. The calculation duration was set to be 72 hours in order to account for the initial discharge. The roughness coefficients, adopted in the model, were 
selected taking into account the mountain relief. Optimal coefficients were 0.08 for all cross-sections. As it can be seen, the maximum discharge was $112.8 \mathrm{~m}^{3} / \mathrm{s}$, the minimum discharge was $41.5 \mathrm{~m}^{3} / \mathrm{s}$. Discharge peak was observed at 48 hours. The maximum crosssection area was $177 \mathrm{~m}^{2}$ (exceeding probability $0.1 \%$ ), the minimum was $102 \mathrm{~m}^{2}(10 \%)$ with an initial area of $66 \mathrm{~m}^{2}$. The water-level for the $1^{\text {st }}$ cross-section varied from $42.4 \mathrm{~m}$ (exceeding probability $0.1 \%$ ) to $41.3 \mathrm{~m}(10 \%)$.

The duration of hazardous events during the Phyllis typhoon for the Susuya river was estimated based on the water discharge data analysis from the hydrological gauge (gauge code: 04118 ). The gauge is located on the territory of Yuzhno-Sakhalinsk and now only water-level is measured there. Before the typhoon (August 3, 1981), a cyclone with intense rainfall passed through the southern part of the island. The duration was set as 168 hours from August 2 to 8 . Thus, the gradual increase in water discharge during the cyclone and the flood wave after the typhoon could be monitored. The maximum water discharge during the typhoon, according to the measurements at this gauge, was $764 \mathrm{~m}^{3} / \mathrm{s}$ on August 6 [8]. The calculation was conducted for the river section between the pedestrian bridge along the A. Blok street and the Molodezhnaya street. Figure 3 shows the hydrographs of the flood and low-density debris flows of different exceeding probabilities at the $3^{\text {rd }}$ cross-section.

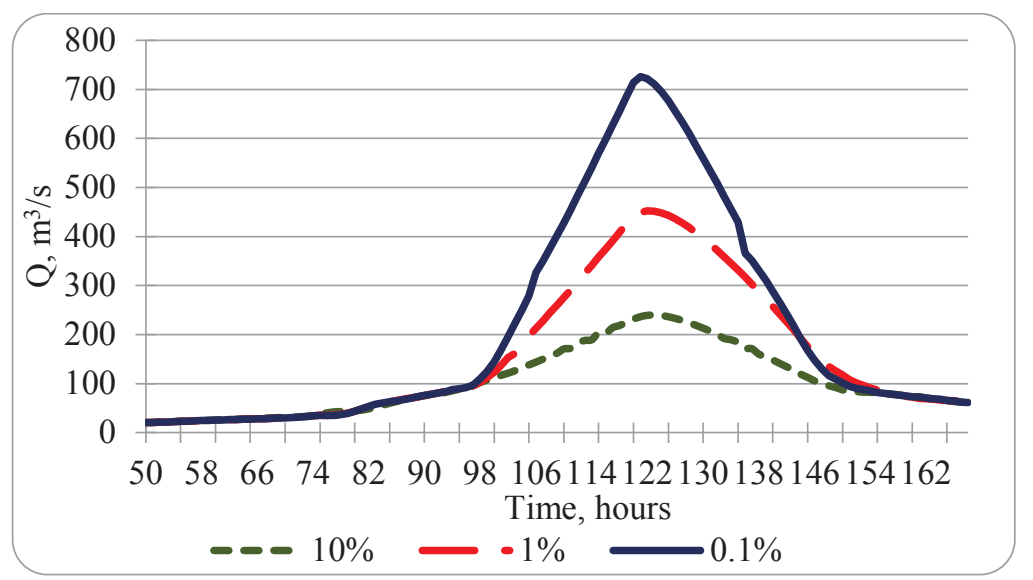

Fig. 3. Calculated hydrographs of various exceeding probabilities for the $3^{\text {rd }}$ cross-section of the Sysya River.

We identified through numerical experiments that the optimal coefficient of roughness was 0.08 for all cross-sections. Maximum flow discharge was equal to $721 \mathrm{~m}^{3} / \mathrm{s}$ at the $3^{\text {rd }}$ cross-section and was observed at $122^{\text {nd }}$ hour. The maximum flow velocity was $3.5 \mathrm{~m} / \mathrm{s}$ for the $3^{\text {rd }}$ cross-section (exceeding probability $10 \%$ ), the minimum was $2.1 \mathrm{~m} / \mathrm{s}$ $(0.1 \%)$. Vast flooding areas were projected for all cases, the cross-sectional area could reach $933 \mathrm{~m}^{2}$ with an initial of $25 \mathrm{~m}^{2}$ (exceeding probability $10 \%$ ). The water-level for the $1^{\text {st }}$ cross-section varied from $29.3 \mathrm{~m}$ (exceeding probability $\left.0.1 \%\right)$ to $27.8 \mathrm{~m}(10 \%)$.

\section{Coclusion}

In this study, the floods and low-density debris flows of various exceeding probabilities were modeled on the Susuya, Vladimirovla and Rogatka rivers. Necessary initial data for modeling such as morphometry and the cases of maximum water discharges and waterlevels were provided by our colleagues from Research Center "Geodinamika". The study revealed the transformation of waveform during floods and low-density debris flows for all study areas. For the Vladimirovka river, the maximum discharge obtained by the model was 
$103.2 \mathrm{~m}^{3} / \mathrm{s}$ for the ultimate cross-section, which is located in $500 \mathrm{~m}$ before the mouth. Flooding of the territory at the ultimate cross-section occurred at the depth of 1.2 and $1.5 \mathrm{~m}$ for 1 and 3 cases of modeling. Then, the experiments were carried out to determine the optimal coefficient of roughness and it was found to be 0.09 for all cross-sections. As for the Rogatka river, the maximum discharge was $112.8 \mathrm{~m}^{3} / \mathrm{s}$, the minimum $-41.5 \mathrm{~m}^{3} / \mathrm{s}$. The maximum derived cross-section area was $173 \mathrm{~m}^{2}$ (exceeding probability $0.1 \%$ ), the minimum was $101 \mathrm{~m}^{2}(10 \%)$ with an initial of $66 \mathrm{~m}^{2}$. Additionally, numerical experiments were conducted to identify the optimal coefficient of roughness, which was equal to 0.08 . As for the Susuya river, the maximum derived discharge was $721 \mathrm{~m}^{3} / \mathrm{s}$ at 122 hour. The maximum flow velocity was $3.5 \mathrm{~m} / \mathrm{s}$ for the $3^{\text {rd }}$ cross-section (exceeding probability $0.1 \%$ ), the minimum was $2.0(10 \%)$. Also, the coefficient of roughness was determined to be 0.08 .

Even though the model of unsteady water movement does not take into account the size and composition of the loss material and the debris flow density, it is a linked system of initial and boundary conditions and gives plausible results. Besides, we can take into account the sediment load of the stream by increasing coefficient of roughness. Moreover, it is necessary to mention that at the output we get a fairly large array of data such as flow discharges, water-levels, cross-sectional area, flow width for the entire period at planned cross-sections. Due to the fact that only one-time measurements were carried out for the Sysya river tributaries, the information obtained by the model can be further used in the design of protective structures.

We thank our colleagues from Research Center "Geodinamika" for the provided data

\section{References}

1. Yu. V. Gensiorovskiy, Glaciological Res. Mat., 102, 73-79 (2007)

2. Yu. V. Gensiorovskiy, N. A. Kazakov, Coll. of sci. proc. of the conf. Geodynamic processes and nat. disasters. Neftegorsk experience, 2, 302-305 (2015)

3. V. Perov, S. Chernomorets, O. Budarina, E. Savernyuk, T. Leontyeva T., Nat. Hazards, 88, 199-235 (2017)

4. L. A. Musohranova, Yu. V. Gensiorovskiy, N. A. Kazakov, Gradostroitelstvo (Urban Planning), 6, 33-39 (2010)

5. M. S. Grushevskij, Unsteady water movement in rivers and channels, 288 (1982)

6. T. A. Vinogradova, A. Yu. Vinogradov, V. A. Kurovskaia, IOP Conf. Ser.: Earth Environ. Sci., 321 (2019)

7. T. A. Vinogradova, V. S. Nikiforovskaya, Coll. of sci. proc. of the IYth Russian conf. on Water Problems, 102-106 (2015)

8. I. S. Bykadorov, Surface Water Resources of USSR. Hydrologic coverage, Far East, Primorye, 18, 83 (1963)

9. N. A. Kazakov, Yu. V. Gensiorovskiy, D. A. Bobrova, et.al., Report on sci. research: Asses. of the possibility of the manifestation of sec. phenomena from earthquakes and their spatial localization in the Sakhalin reg.: the danger of channel proc. and floods in Yuzhno-Sakhalinsk c., 2, 225 (2015)

10. E. N. Kazakova, Geoecology, Engineer. Geology, Hydrogeol., Geocryol., 3, 258-263 (2009)

11. E. N. Kazakova, A. A. Muzychenko, Gerisk, 3, 34-38 (2014) 